\title{
Erkki Lyytikäinen
}

\section{Kirjallisuuteus on kirjallisuuden kova ydin}

Markus Lång (2011) on tyytymätön uudissanaani kirjallisuuteus (Lyytikäinen 2010), jolla ehdotan käännettäväksi venäjän termin literaturnost'. Lång puoltaa sanaa kirjallisuudenomaisuus.

Långin kannattamassa termissä on monta ongelmaa. Kirjallisuudenomaisuus on ensinnäkin termiksi toivottoman pitkä. Toiseksi se ei ole termi lainkaan vaan lähinnä selite. Mutta mikä pahinta, selitteeksi se on väärä. Semantiikka ei täsmää. Tämän huomaa, kun miettii vaikkapa suomen sanaa tutunomainen. Sen merkitys on "ikään kuin tuttu; tutulta tuntuva; lähes tuttu”. Tämän mukaisesti sanan kirjallisuudenomainen merkitys on "kirjallisuutta muistuttava, kirjallisuudelta tuntuva" tjs. ja kirjallisuudenomaisuus on vastaava ominaisuudennimi. Sen sijaan literaturnost, kirjallisuuteus on kirjallisuuden kova ydin, se mikä tekee kirjallisuudesta kirjallisuuden, ei mitään vähän sinne päin.

Kielitoimistosta saamani tiedon mukaan suomen kielen lautakunta ei ole käsitellyt kirjallisuudenomaisuus-sanaa. Sen sijaan toimisto on kyllä parikymmentä vuotta sitten tarjonnut sitä käyttöön asiakkaan kysymyksen johdosta.

Kirjallisuuteus ei toki ole kielenvastainen. Se on vain uutuuttaan outo - kuten kaikki uudismuodostelmat, kunnes vakiintuvat.

\section{Lähteet}

LÅNG, MARKUS $20 \mathrm{I}$ I: Kirjallisuudenomaisuutta on suositeltu. Avain 2, 68. LYYTIKÄINEN, ERKKI 20IO: Kirjallisuuden ydin: kirjallisuuteus. Avain 3, 65-66. 